\title{
Interactive Technologies in Teaching a Foreign Language at Higher Educational Establishment

\author{
GORBANYOVA Oksana
}

\author{
Oles Honchar Dnipropetrovsk National University, Ukraine \\ E-mail address: oks.alex@ua.fm
}

\begin{abstract}
Keywords: interactive technology, interactive method, communication, dialogue, discussion, brainstorming, case, project, role play, presentation.
\end{abstract}

\begin{abstract}
The purpose of this study is to analyse the effectiveness of using interactive technologies in the process of teaching a foreign language at a higher educational institution. The principal result of our research is the analysis of the influence of using interactive techniques on acquiring communicative competence and personal development. The major conclusions estimate the significance of applying interactive technologies in learning process.
\end{abstract}

\section{INTRODUCTION}

Nowadays, the importance of teaching a foreign language effectively has grown significantly in the world, especially in developing countries, such as Ukraine. According to the new decree, the year of 2016 in Ukraine has been declared "The Year of English" by our president Petro Poroshenko. "Considering the role of English as a language of international communication, to promote its study to expand public access to the world's economic, social, educational and cultural opportunities offered by the knowledge and use of English, ensuring the integration of Ukraine into the European political, economic, scientific and educational space for the support of the program "Go Global", which defines learning English a priority development strategy" [1]. A complex of measures is being taken to intensify English learning in Ukraine. Among them is raising teaching standards at all stages of education, which means improving both teachers' proficiency and methods of teaching.

As it is known, today there is an important shift from passive to active learning. Therefore, special attention is paid to strengthening the technological aspects of specialist training and implementation-centered approach to the learning process where the student takes an active part in cognitive activity. Foreign language teachers must find ways to increase the level of students' involvement in the process of studying, to raise their motivation for learning languages. One way to reach these goals is using interactive technologies at classes. It helps to develop students' creativity, imagination, increase their cognitive interest in studying foreign languages and improve their communicative skills. The term "interactive learning technology" is usually connected with computer or multimedia learning, as it implies interactive dialogue with real partners and direct exchange of messages. But this notion is wider and means collective cognitive activity where all participants interact, exchange information, solve problems in atmosphere of real collaboration, estimate their own actions [2].

The problem of using the interactive methods of teaching foreign languages at the higher educational establishments was also studied by R. Blair [3], S. Martinelli [4], L. Konoplianyk [5], H. Stern [6], E. Polat [7], M. Tailor [4] and others.

Interactive learning technologies include clearly planned learning results, interactive methods, tools, and forms stimulating the learning process, cognitive and mental conditions and procedures for achieving planned results [8]. Thus, interactive technology comprises a scope of interactive methods that a teacher uses in his work.

Modern methodology defines method as a way to reach a goal. There are different points of view at the classification of interactive learning methods. For example, Panina and Vavilova group interactive methods into discussions, games and trainings [9, p. 11]. Holant first classifies teaching 
methods depending on the degree of involvement in the studying process and divides them into active and passive ones [8, p. 8]. Smith and Kochubey, following Holant, divide teaching methods into passive and interactive ones. Passive methods include reading, working with literature, etc.

Interactive technologies of teaching foreign languages are based on activity-based approach and comprise the use of interactive teaching methods, including non-situational (dialogue) and situational (game, simulation, analysis of situations, auction ideas, etc.); organic combination in the educational process of various learning tools (electronic and paper-based information), innovational (distance-learning) and traditional forms of education on the principles of the appropriateness of their implementation and complementarity[8]. The basis of interactive learning is a direct dialogue student - teacher, student - student, students - guest. It can be one lesson, a series of lessons or the whole course.

Such classification reflects the main features of interactive methods of teaching foreign languages: activity, collectivity and situational training activities; developing students' reflective skills, attention, imagination, observation, innovative thinking; educational consistency, logic, critical thinking and creativity, efficiency, curiosity, cognitive independence and persistence in achieving goals.

\section{METHODOLOGY}

Interactive technologies can be characterized by the presence of a dialogue, exchange of opinions and arguments for and against the disputable matter. Any lesson based on discussion is effective if the participants have basic knowledge of the issue and if a teacher has planned the main stages and key points in advance. During the planning stage a teacher chooses and formulates an issue, plans ways of stimulating and monitoring participants' activity. He must prepare necessary equipment to record students' ideas. When the discussion starts, the teacher performs as an intermediary. It is very important to perceive different points of view on a particular problem, to have his own opinion, to be able to make conclusions and evaluate achievements. You can use various techniques of introducing the topic to the audience: describe problematic situation, put problem questions, show video, role play of the situation, presenting a few opinions on an issue. A discussion should comprise different points of view which at the end evolve the decision.

One effective kind of discussion is a "round- table" technique. 10-15 students are seated around the table and discuss a particular problem. A host has a leading role; it can be a student or a teacher. The aim of the activity is not to find a final solution, but to discuss the problem, collect as much information as possible, realize the importance of solving the problem, find ways to reach the goals. When students sit at a round table, they have eye contact with all members of discussion, everyone feels involved and equally important. It stimulates conversation, increases the number of utterances and encourages using non-verbal means of communication (miming, gestures). A "round-table" technique can be combined with a role play or a business play.

Project method is a complex of research, data processing and other activities carried out by students on their own or in small groups with a view to practical or theoretical solution of a significant problem. Project-based learning involves a fundamentally different philosophy of building the educational process through students' purposeful activity in accordance with personal interest and goals.

It is obvious that the project method opens up opportunities for students to express themselves, to identify their skills and to outline future professional activity. In other words, the student receives an opportunity to try and test himself in different areas, to reveal something intimate and interesting and focus at his desires, strengths and abilities. And, most importantly, all his activities are focused on the formation of his thinking, which is based on personal experience. He shares responsibility for his own development, the level of training for self-employment in the future.

Method of projects always provides a solution to some problem. A solution to the problem involves, on the one hand, the use of combination of various methods and means of education, and 
on the other - the need for the integration of knowledge and skills from different fields of science, engineering, technology and creative areas. The main objectives of project-based learning are:

- creating the conditions in which students independently and willingly acquire the missing knowledge from different sources;

- learning to use the acquired knowledge to solve practical and cognitive problems;

- acquiring communication skills by working in different groups;

-developing their research skills (the ability to identify problems, gather information, observations, experiments, analysis, construction of hypotheses, generalizations);

- developing systematic thinking.

In foreign methodical literature there are the following stages of the project:

- defining a project theme, a problem, objectives;

- discussing a project structure, composing a plan;

- presenting language material;

- collecting information;

- analyzing and discussing data in groups with a teacher;

- preparing presentation;

- demonstration of project results;

- evaluation of a project.

The last phase includes not only control of mastering linguistic material and development of speech and communicative competence, but also an overall assessment of the project, which concerns the content of the project, the theme, the final result, the participation of individual students in the organization of the project work and so on.

Project-based learning involves essentially the use of a wide range of research techniques, important for the student, on the one hand, and on the other, for the development of the problem holistically, taking into account a variety of factors and conditions for its solution and implementation of results. Project-based learning has been widely used in many countries around the world, mainly because it allows you to seamlessly integrate students' knowledge from different areas around the solution of a problem, makes it possible to apply this knowledge in practice, at the same time generating new ideas. As it was mentioned before, at the heart of the project there is some problem. To solve it, students need not only knowledge of the language, but also the possession of a large amount of subject knowledge, necessary and sufficient to deal with the problem. In addition, students must possess certain intellectual, creative, communicative abilities. They include the ability to work with information, with a text (highlight the main idea, search for the right information in a foreign language text), to analyze information, make generalizations, conclusions, etc., the ability to work with a variety of reference material. Formation of these skills is the aim of teaching different types of speech activity.

\section{RESULTS}

One of the most effective activities is a discussion on various topics at the lesson. Discussions on professionally-oriented topics are useful for students' future communication at a working place, enriching their vocabulary in a definite sphere. A teacher should involve students in a discussion after reading an article or a text which is connected with their future job. A teacher organizes, facilitates the discussion by formulating the questions, pointing out interesting, original ideas, contradictive issues, helping to settle disagreements. 
Brainstorming is a very effective kind of discussion that involves all students into the activity. A teacher announces a topic, a goal of discussion, rules for participants and criteria for evaluating ideas. Then experts and secretaries are elected or appointed. For example, the teacher tells his students of economic faculty: "Dear ladies and gentlemen! Our company's sales figures are not as good as the last year's. What could we do to attract customers?" Every student generates ideas which are written down by the secretaries. The main rule both for a teacher and a student is that criticism is banned. All ideas must be accepted at this stage. A teacher encourages students' participation. Students can improve their group mates' ideas. They can even quit their own idea and stick to another. Every student talks a few times, but very briefly - within one minute. At the next stage of the activity all ideas are estimated, grouped and the most acceptable ones are selected.

To increase a number of ideas, teachers can use following techniques: the stepladder brainstorming, brainwriting, online brainstorming (brain-netting), rolestorming, Crawford's Slip Written approach [9], etc.

Role play is one of the most popular techniques among foreign language teachers. It has a great motivating factor and helps to energize the class. It is suitable for students of any age group or language level. Every student has a definite role to play; he/she is involved in a situation which requires communication. If a student is usually shy or reluctant to speak, while pretending to be someone else, he/she eagerly participates. A business play is a kind of a role play which has similar rules and procedure, but the difference is that students are involved in the activity that is connected with their future professional life. Students have business functions, relations as they are in reality. Business play is an effective tool for both language learning and training for future job at higher educational institutions.

Students of our university are usually very eager to participate in a business play, as they are rather mature and have ambitions for future professional activity. As an example, we can describe the business play "Starting a business". Students are offered roles of managers in their company (a top manager, a sales manager, a finance manager, an HR manager, etc.). A president of a company is elected. A group receives the task to start a business in any sphere; it can be a production or sale, service or advertising business. A discussion starts. When students have reached agreement, they create company's name and logo. Then every department receives a task from a president or a chief executive officer (CEO), which is done after a lesson. Next meetings can be devoted to creating a business plan, conducting a market research, making advertisement for their product or service. Such interactive technique combines a business play with a discussion, a case and a project.

The application of role plays in general, and business plays in particular, increases students' motivation for cognitive activity, acquiring knowledge and communicative skills in a foreign language. It creates positive psychological atmosphere in a classroom.

Creating problematic situations, the teacher ensures that the material corresponds to the level of existing knowledge and intellectual opportunities of the group, reflects the real situation of professional activity, is also related to the topic of future job, the text they read, grammar they learned. In carrying out these tasks, students can understand the information presented in the text, activate lexical and grammatical material.

At universities students' professional presentations become more and more widespread kind of academic activity. Through presentation the material is delivered in a most effective way due to its visibility and demonstrativeness. Presented material is varied and comprises text and picture slides, various visual images with verbal explanations, movie and audio fragments [10]. Multimedia presentation is an innovative technique in teaching foreign languages. During the stage of preparation students must do a lot of research, study various sources of information, which helps to develop creativeness and individual approach to learning. Preparation stage includes choice of the topic, search of information, data processing and arranging the material into presentation. Next stage is delivering a presentation, which should be thoroughly planned. Then a group can have a discussion based on presentation data. Finally, a teacher can ask students to write an opinion essay.

Case is a situation described in a form of a story that needs solution. Usually, this story begins with a description of the most important facts about an organization or institution concerned, such 
as historical data on its development and description of the situation at present. The goal of a case study technique is the formation of students' problem-oriented thinking and developing skills in management decisions based on the analysis of complex real situations, identifying problems and opportunities, analyzing alternatives and finding the best of them, with the recommendations for remedial action. To deal with a case, students are divided into groups (a team or a consulting group) of four-five students. The leader of the group is elected. As a result of a discussion, a report is prepared and presented by the group. This stage aims to gain public speaking skills in addition to all abovementioned. Next stage is a discussion involving all groups of students. They should ask questions, providing their comments and indicating the most successful discoveries of the case study of the situation. Finally, the teacher makes general comments and recommendations.

\section{DISCUSSION}

Having more than twenty years of teaching experience at the university, the faculty of international economics, we can state that the effectiveness of learning a foreign language depends on teaching methods greatly. Our students are future economists, managers, businessmen. They must speak at least one foreign language fluently for getting a perspective job and being successful at it. Nowadays teachers are not supposed only to deliver information to students, such passive approach is not effective at all. A lot of articles are written, speeches are made, seminars are held, but still some lecturers stick to outdated approach of students' passive receiving information. As for foreign language teaching, the shift towards active learning took place long ago. Teachers of our department of foreign languages do their best to get students involved in the process of learning with the help of interactive methods, such as role and business plays, problem solving, brainstorming, etc. Every unit starts with discussing a problem issue. During the lesson students are engaged in communication in pairs, small groups, whole class, with a teacher or a guest. Final step of working with a unit is usually a presentation or a project. For example, studying unit "Marketing", groups conduct real market research, choosing a definite product or service. According to the results of the research, they create an advertisement and present it to the rest. It takes a few weeks and combines such interactive methods as projects, brainstorming and presentation.

Applying interactive technologies in a foreign language classroom at the university has proved very effective and motivating for students of any age group and level of mastering a foreign language. Those students who are not used to interactive activities find it difficult at first to participate in discussions or dialogues, but gradually they learn and start feeling as important in their group as the others. Students usually like playing roles of managers, businesspeople. When they act, they do not think much about grammar mistakes, and a teacher shouldn't correct them while speaking. Necessary correction can be done after the activity without mentioning names. Fulfilling a case study or a project requires students' creativity, rich imagination, logical thinking. Ukrainian students are very talented and smart, so such tasks are effective techniques to reach the aim of teaching process - to teach students communicative competency. In other words, modern interactive teaching methods make it possible to shift educational process from ineffective methods of knowledge transfer to promoting foreign communicative competence to university students, ensuring the implementation of systematic activity approach and student-centered learning.

As students have fewer and fewer academic hours for classwork, having more and more hours for self-study, according to the curriculum, time is precious at the lesson. But they can read an article, do written exercises and tasks at home, in order to use class time efficiently.

\section{CONCLUSIONS}

Interactive technologies are based on dialogical communication between a student and a teacher, so learning process involves all students in cognitive activity. It means that there takes place exchange of ideas, knowledge and experience. Participating in interactive activities, students learn to cooperate, think logically, analyze information, solve problems. Necessary conditions for 
effective language learning are free communication, expressing opinions and mutual respect. Implementing interactive technologies in teaching process at university, we have made the conclusions that they improve students' communicative skills and raise motivation; develop their personal, intellectual and social competencies; create positive atmosphere in class.

Students of universities must be competitive in their future professional sphere. Mastering the English language is one of the priorities for any specialist. Modern world requires strengthening general cultural foundation of education, skills development to activate personal capacity to deal with social problems. Highly professional graduates who do not just follow instructions, but have creative and constructive potential, are demanded.

It is obvious that there cannot be one universal scheme of organizing learning process. Lesson structure depends on goals, contents, target audience, etc. Using interactive technologies is not an objective, but it is a means of creating necessary conditions for communicatively effective learning. It encourages individuals' cooperation, self-development, improves both skills of foreign language communication and personality traits.

\section{References}

[1] Information on http://www.president.gov.ua/UKRAINE Presidential Decree №641 / 2015 About Declaring 2016 Year of English in Ukraine.

[2] T.S. Panina, L.N. Vavilova, Modern methods of activization of training, Handbook for students, ed. by T.S. Panina, $4^{\text {th }}$ ed., Moscow, 2008.

[3] R.Blair, Innovation approaches to language teaching, New York, Newbury House, 2010.

[4] S.Martinelli, M.Tailor, Intercultural Learning, Strasbourg, Council of Europe and European Commission, 2000.

[5] L.Konoplyanik, Interactive methods of teaching foreign languages in higher Education in: Materials of II International Scientific Conference "Modern trends in teaching a second language at schools and institutions of higher education ", Gorlovka, HDPIM, 2011. - p.p. 84-85.

[6] H.Stern, Fundamental Concepts of Language Teaching, Oxford, Oxford University Press, 1983.

[7] E.S. Polat, New pedagogical and information technology in education, Tutorial for students of pedagogical colleges, Moscow, Publishing center «Academy», 2000.

[8] O.I. Pometun, Current lesson. Interactive learning technologies, scientific method, Kyiv, Publishing A.S.K., 2004.

[9] Information on https://www.mindtools.com/brainstm.html Brainstorming: Generating Many Radical, Creative Ideas.

[10] O.B. Tarnopolskiy, Successful presentations: textbook for teaching business presentations in English students of economic specialities, Kyiv, Lenvit, 2007.

[11] J. Richards and Th. S. Rodgers, Approaches and Methods in Language Teaching, Cambridge University Press, 2001.

[12] Information on http://shodhganga.inflibnet.ac.in/bitstream/10603/4359/7/07_chapter\%202.pdf 